\title{
Kapasitas Stabilisasi Radikal Bebas dan Kelasi Ion Metal Ekstrak Air Daun Vernonia amygdalina Del.
}

\author{
Free Radical Stabilization and Metal Ion Chelation Capacities of Vernonia amygdalina Del. \\ Leaves Water Extracts
}

\author{
Gino Nemesio Cepeda ${ }^{1 *}$, Murtiningrum ${ }^{1}$, Yuliana Waromi ${ }^{2}$ \\ ${ }^{1}$ Jurusan Teknologi Pertanian, Universitas Papua \\ ${ }^{2}$ Alumni Jurusan Teknologi Pertanian, Universitas Papua \\ "Email: ginocepeda.gc@gmail.com
}

\begin{abstract}
The medicinal plant of Vernonia amygdalina known as "Daun Afrika" is an original plant of Afrika. The plant is used for healing malaria, diabetes, digestion disorder, and sexually transmitted diseases. The objectives of the study were to evaluate the antioxidant potency of "Daun Afrika" water extracts including phenolic compound contents, the capacities of stabilizing free radicals by transferring hydrogen atoms, and chelating metal ions by transferring electrons at varied extract concentrations. The Extraction process of bioactive compounds used infusion method with hot water $90^{\circ} \mathrm{C}$ for 30 minutes. Determination of antioxidant properties of extracts including phenolic compound contents with Folin-Ciocalteu method, free radical stabilization capacities using DPPH (1,1-Diphenyl-2picrylhydrazyl) free radical scavenging method, and metal ions chelation using ferrous ions chelation method. The result showed that water extracts of "Daun Afrika" at a concentration of 0.1-0.5\% had phenolic compounds of 18,81-69.89 $\mu \mathrm{g}$ EAG/ml, DPPH free radical scavenging capacities about 20,99-41,98\% and ferrous ions chelation activity of 8,28-40,71\%. The water extract of "Daun Afrika" had less potential as a source of natural antioxidant for stabilizing free radicals but it was very effective to chelate metal ions prooxidant
\end{abstract}

Keywords: Antioxidant, Vernonia amygdalina leaves extracts, free radicals

\begin{abstract}
Abstrak
Tumbuhan obat Vernonia amygdalina dikenal dengan nama "Daun Afrika" adalah tumbuhan yang berasal dari Afrika. Tumbuhan ini digunakan untuk mengobati malaria, infertilitas, diabetes, gangguan pencernaan dan penyakit transmisi seksual. Tujuan penelitian ini adalah mengevaluasi potensi antioksidan ekstrak air daun afrika yang meliputi kandungan senyawa fenolik, kapasitas stabilisasi radikal bebas melalui transfer atom hidrogen dan kelasi ion metal sebagai prooksidan melalui transfer elektron pada variasi konsentrasi. Proses ekstraksi senyawa bioaktif daun afrika menggunakan metode infusi dengan air panas suhu $90^{\circ} \mathrm{C}$ selama 30 menit. Pengujian aktivitas antioksidan ekstrak meliputi penentuan kandungan senyawa fenolik menggunakan metode Folin-Ciocalteu, pengujian kapasitas stabilisasi radikal bebas menggunakan metode stabilisasi radikal bebas DPPH (1,1-Diphenyl-2picrylhydrazyl) dan pengujian kapasitas kelasi ion metal menggunakan metode kelasi ion metal $\mathrm{Fe}^{+2}$. Hasil pengujian menunjukkan bahwa ekstrak air daun afrika konsentrasi 0,1-0,5\% mengandung senyawa fenolik sebesar 18,81-69.89 $\mu \mathrm{g}$ EAG/ml, kapasitas stabilisasi radikal bebas DPPH sebesar 20,99-41,98\% dan kapasitas kelasi ion metal $\mathrm{Fe}^{+2}$ sebesar 8,28-40,71\%. Ekstrak air daun afrika kurang berpotensi sebagai sumber antioksidan alami dalam menstabilkan radikal bebas namun demikian sangat efektif mengikat ion metal yang bersifat prooksidan.
\end{abstract}

Kata kunci: Antioksidan, ekstrak daun Vernonia amygdalina, radikal bebas 


\section{PENDAHULUAN}

Tumbuhan merupakan sumber senyawa fitokimia yang melimpah. Senyawa fitokimia yang dikenal juga sebagai senyawa metabolit sekunder merupakan senyawa yang memiliki aktivitas biologik yang bersifat melindungi tumbuhan dari kerusakan, penyakit dan memberikan warna, aroma serta flavor pada tumbuhan (Saxena dkk., 2013). Senyawa metabolit sekunder telah lama digunakan sebagai obat, pembangkit rasa pada pangan, terapi aromatik, insektisida dan pewarna (Pagare dkk., 2015).

Vernonia amygdalina merupakan tumbuhan obat tradisional yang berasal dari Afrika tropis dan telah tersebar luas di Asia yang dapat ditemukan sepanjang jalur drainase, hutan alam dan perkebunan komersial (Kadiri dan Olawoye, 2016). Di Indonesia tumbuhan ini dikenal dengan nama "Daun afrika" sedangkan di Afrika tumbuhan ini dikenal dengan beberapa nama diantaranya "Ewuro" (Yoruba) "Onugbu" (Igbo), "Oriwo" (Bini), "Ityuna" (Tiv), "Chusardoki atau fatefate" (Hausa) dan "Etidot" (Ibiobio) (Ojimelukwe dan Amaechi, 2019). Tumbuhan Vernonia amygdalina di Afrika digunakan untuk mengobati malaria, infertilitas, diabetes, gangguan pencernaan dan penyakit transmisi seksual (Farombi dan Owoeye, 2011).

Beberapa penelitian menunjukkan bahwa ekstrak daun afrika mengandung senyawa fenolik dan flavonoid. Ekstrak metanol, etilasetat dan heksan tumbuhan ini dilaporkan mengandung total fenol masingmasing 1,77, 4,40 dan dan 1,70 mg EAG/g (Tosa, 2018), sedangkan ekstrak etanolnya mengandung flavonoid sebesar $14,85 \mathrm{mg}$ EQ/g (Sukmawati dkk., 2017). Senyawa flavonoid penyusun daun afrika adalah luteolin, luteolin7-O-glukosida dan luteolin-7-O-glukuronida (Farombi dan Owoeye, 2011).

Hasil penelitian senyawa penyusun ekstrak daun afrika menunjukkan bahwa ekstrak tumbuhan ini berpotensi sebagai sumber antioksidan alami karena mengandung senyawa fenolik yang telah diketahui memiliki aktivitas antioksidan yang kuat. Antioksidan merupakan senyawa yang dapat menghambat, mencegah dan menghilangkan kerusakan oksidatif terhadap molekul target (Yadav dkk., 2016). Pengujian potensi antioksidan ekstrak tumbuhan dapat dilakukan secara in vitro. Pengujian potensi antioksidan secara in vitro dapat dilakukan menggunakan dua metode, yaitu metode transfer atom hidrogen yang bertujuan untuk mengukur kemampuan antioksidan memberikan atom hidrogen terhadap radikal bebas sedang metode transfer elektron menentukan kemampuan ekstrak memberikan elektron untuk mereduksi metal yang bersifat prooksidan dan radikal bebas (Kasote dkk., 2015).

Beberapa penelitian tentang potensi ekstrak daun afrika sebagai antioksidan telah dilakukan. Ekstrak fraksi n-heksan daun afrika dapat menstabilkan radikal DPPH dengan konsentrasi penghambatan $50 \%\left(\mathrm{IC}_{50}\right)$ sebesar 371,98 ppm (Fatimah dan Sundu, 2020), ekstrak metanol dan etanol daun afrika memiliki $\mathrm{IC}_{50}$ terhadap radikal DPPH masingmasing sebesar $175,021 \mathrm{ppm}$ dan $3.289 \mathrm{ppm}$ (Febrianti dkk., 2017; Nurlatifah dkk., 2018).

Saat ini informasi tentang potensi antioksidan ekstrak air daun afrika masih sangat terbatas terutama kapasitas antioksidan ekstrak sebagai penyumbang atom hidrogen terhadap radikal bebas dan penyumbang elektron pada senyawa prooksidan. Oleh sebab itu penelitian ini bertujuan mengevaluasi potensi antioksidan ekstrak air daun afrika yang meliputi kandungan senyawa fenolik, kapasitas stabilisasi radikal bebas melalui transfer atom hidrogen dan kelasi ion metal sebagai prooksidan melalui transfer elektron pada variasi konsentrasi. Hasil penelitian ini diharapkan memberikan informasi potensi ekstrak air daun afrika sebagai antioksidan alami secara in vitro yang lebih komprehensif.

\section{METODOLOGI}

\section{Bahan dan alat}

Beberapa jenis bahan yang digunakan dalam penelitian ini adalah bahan utama penelitian daun Vernonia amygdalina yang diperoleh dari Distrik Manokwari Barat dan bahan untuk analisis antioksidan yang meliputi aquades, metanol (JT Baker), reagen FolinCiocalteu, asam galat dan ferrozine (Zigma), sodium karbonat dan $\mathrm{FeCl}_{2}$ (Unilab), DPPH (1,1-Diphenyl-2-picrylhydrazyl) dan vitamin C (Merck). Sedangkan peralatan yang digunakan meliputi peralatan untuk ekstraksi yaitu grinder (Miyako Indonesia), ayakan ukuran 40 mesh (ASTM USA), corong penyaring Buchner, pompa vakum, kertas saring whatman no. 1 dan peralatan untuk analisis antioksidan yang meliputi timbangan analitik (Radwag 
Was220/C/2 Polandia), mikropipet (Pipet-One Rainin) dan tips, vortex (Heidolph Tipe : REAX top), spektrofotometer (tipe UVmini1240 Shimadzu Jepang) dan beberapa peralatan gelas.

\section{Metode}

Pelaksanaan penelitian ini menggunakan metode eksperimen dan rancangan penelitian yang digunakan adalah rancangan acak lengkap (RAL). Perlakuan yang diaplikasikan terdiri dari perlakuan konsentrasi ekstrak air daun afrika, yaitu 0 , $0,1,0,2,0,3,0,4$ dan $0,5 \%$. Setiap level perlakuan konsentrasi tersebut dilakukan uji kapasitas stabilisasi radikal bebas dan kapasitas pengikatan $\mathrm{Fe}^{+2}$. Setiap perlakuan konsentrasi dilakukan pengujian dengan tiga kali replikasi.

\section{Preparasi Bahan Penelitian}

Daun afrika yang dipergunakan dalam penelitian ini adalah daun afrika berwarna hijau tua. Bahan daun afrika dibersihkan dengan air mengalir untuk mengeluarkan debu dan kotoran yang menempel. Daun afrika yang sudah bersih dikering-anginkan dalam ruangan selama kurang lebih 7 hari sampai daun menjadi rapuh dan mudah dihancurkan. Daun yang sudah kering selanjutnya dihancurkan menggunakan grinder dan diayak dengan ayakan ukuran 40 mesh. Bubuk daun yang diperoleh dikemas dalam wadah plastik.

\section{Ekstraksi Komponen Fitokimia}

Senyawa antioksidan dalam bubuk daun afrika diekstrak menggunakan aquades. Metode ekstraksi yang diterapkan dalam proses ekstraksi senyawa antioksidan daun afrika adalah metode infusi (Handa dkk., 2008). Sejumlah 25 gram bubuk daun afrika dimasukkan ke dalam labu Erlenmeyer kemudian ditambahkan aquades yang bersuhu $90^{\circ} \mathrm{C}$ sampai volume total campuran bubuk daun afrika dan aquades dalam labu Erlenmeyer mencapai $100 \mathrm{ml}$. Labu Erlenmeyer selanjutnya ditutup rapat untuk mencegah penguapan air dan dibiarkan proses ekstraksi selama 30 menit. Setelah waktu infusi berakhir, campuran bubuk daun afrika dan aquades disaring vakum menggunakan pompa vakum yang dilengkapi dengan Buchner. Supernatan hasil penyaringan adalah ekstrak kasar dengan konsentrasi 25\%. Ekstrak tersebut digunakan sebagai stok ekstrak untuk pengujian. Ekstrak yang digunakan dalam pengujian adalah stok ekstrak yang telah diencerkan menjadi konsentrasi 0,1-0,5\%.

\section{Penentuan Kandungan Total Fenol}

Kandungan senyawa fenol dalam ekstrak kasar daun afrika diuji menggunakan metode Folin-Ciocalteu (Islam dkk., 2016). Kandungan senyawa fenol ditentukan berdasarkan kurva standar asam galat. Kurva baku asam galat ditentukan mengikuti prosedur di bawah ini: sejumlah 0,5 ml tiap-tiap larutan asam galat dalam metanol dengan konsentrasi $0-100 \mu \mathrm{g} / \mathrm{ml}$ ditambahkan larutan reagen Folin-Ciocalteu (pengenceran 10 kali) sebanyak 2,5 $\mathrm{ml}$ dan sodium karbonat $(75 \mathrm{~g} / \mathrm{L})$ sebanyak $2,5 \mathrm{ml}$. Selanjutnya larutan tersebut diaduk menggunakan vorteks dan diinkubasi 30 menit pada suhu ruang. Setelah waktu inkubasi berakhir, absorbansi larutan ditentukan menggunakan alat spektrofotometer dengan panjang gelombang $765 \mathrm{~nm}$. Kurva standar asam galat ditentukan terhadap nilai absorbansi larutan sebagai sumbu Y terhadap konsentrasi asam galat sebagai sumbu $\mathrm{X}$.

Prosedur yang sama dilakukan untuk menentukan kandungan senyawa fenol ekstrak daun afrika dengan konsentrasi 0-0,5\%. Kandungan senyawa fenolik ekstrak air daun afrika dinyatakan sebagai total fenol yang dinyatakan dalam satuan $\mu \mathrm{g}$ ekivalen asam galat $(\mathrm{EAG}) / \mathrm{ml}$.

\section{Penentuan Kapasitas Stabilisasi Radikal Bebas}

Pengujian kapasitas stabilisasi ekstrak daun afrika terhadap radikal bebas dilakukan menggunakan metode stabilisasi radikal bebas DPPH (Cepeda dkk., 2018). Sejumlah 1,0 ml larutan DPPH $0,3 \mathrm{mM}$ dalam metanol ditambahkan 1,0 $\mathrm{ml}$ larutan yang mengandung ekstrak masing-masing dengan perlakuan variasi konsentrasi $0-0,5 \%$ dan pelarut metanol sebanyak 1,0 ml. Larutan kemudian diinkubasi dalam ruang tanpa cahaya selama waktu 10 menit. Setelah itu larutan diukur nilai absorbansinya menggunakan alat spektrofotometer pada panjang gelombang sebesar $517 \mathrm{~nm}$. Kapasitas stabilisasi radikal bebas (KSRB) ditentukan menggunakan persamaan KSRB $(\%)=[(\mathrm{A} 0-\mathrm{A} 1) / \mathrm{A} 0] \mathrm{x}$ 100\%; dimana $\mathrm{A}_{0}$ adalah absorbansi larutan tanpa ekstrak dan $\mathrm{A}_{1}$ adalah absorbansi larutan ekstrak daun afrika. 


\section{Penentuan Kapasitas Kelasi Ion Metal}

Penentuan kapasitas kelasi ion metal ekstrak daun afrika dilakukan terhadap ion metal $\mathrm{Fe}^{+2}$ (Indracanti dan Sivakumar, 2019). Sejumlah $0,5 \mathrm{ml}$ larutan ekstrak masingmasing dengan variasi konsentrasi $0-0,5 \%$ ditambahkan dengan $0,12 \mathrm{ml}$ larutan $\mathrm{FeCl}_{2}$ dengan konsentrasi $2 \mathrm{mM}$. Larutan tersebut selanjutnya ditambahkan $0,4 \mathrm{ml}$ larutan ferrozine dengan konsentrasi $2 \mathrm{mM}$ dan $6 \mathrm{ml}$ aquades. Larutan selanjutnya diaduk menggunakan pengaduk vortex dan diinkubasi pada suhu ruang selama 10 menit. Setelah itu larutan diukur absorbansinya pada panjang gelombang $562 \mathrm{~nm}$. Kapasitas kelasi ion metal (KKIM) ditentukan menggunakan rumus: $\operatorname{KKIM}(\%)=[(\mathrm{A} 0-\mathrm{A} 1) / \mathrm{A} 0] \times 100 \%$; dimana $\mathrm{A}_{0}$ adalah nilai absorbansi larutan tanpa ekstrak dan $\mathrm{A}_{1}$ adalah nilai absorbansi larutan ekstrak daun afrika.

\section{Analisis data}

Data yang diperoleh dari hasil pengujian dianalisis menggunakan metode analisis regresi. Data hasil analisis regresi ditampilkan dalam bentuk grafik.

\section{HASIL DAN PEMBAHASAN}

\section{Kandungan Senyawa Fenolik}

Kandungan senyawa fenolik ekstrak air daun afrika ditentukan berdasarkan kurva baku asam galat. Kurva baku asam galat dibuat dengan cara regresi linear antara konsentrasi asam galat $0-100 \mu \mathrm{g} / \mathrm{ml}$ terhadap nilai absorbansi pada masing-masing konsentrasi. Hasil penentuan kurva baku konsentrasi asam galat terhadap nilai absorbansi pada tiap konsentrasi menghasilkan persamaan regresi linear $\mathrm{Y}=0,009 \mathrm{X}+0,035$ dengan nilai $\mathrm{R}^{2}=$ 1,00 , dimana $\mathrm{Y}$ adalah nilai absorbansi larutan asam galat dan $\mathrm{X}$ adalah konsentrasi larutan asam galat (Gambar 1).

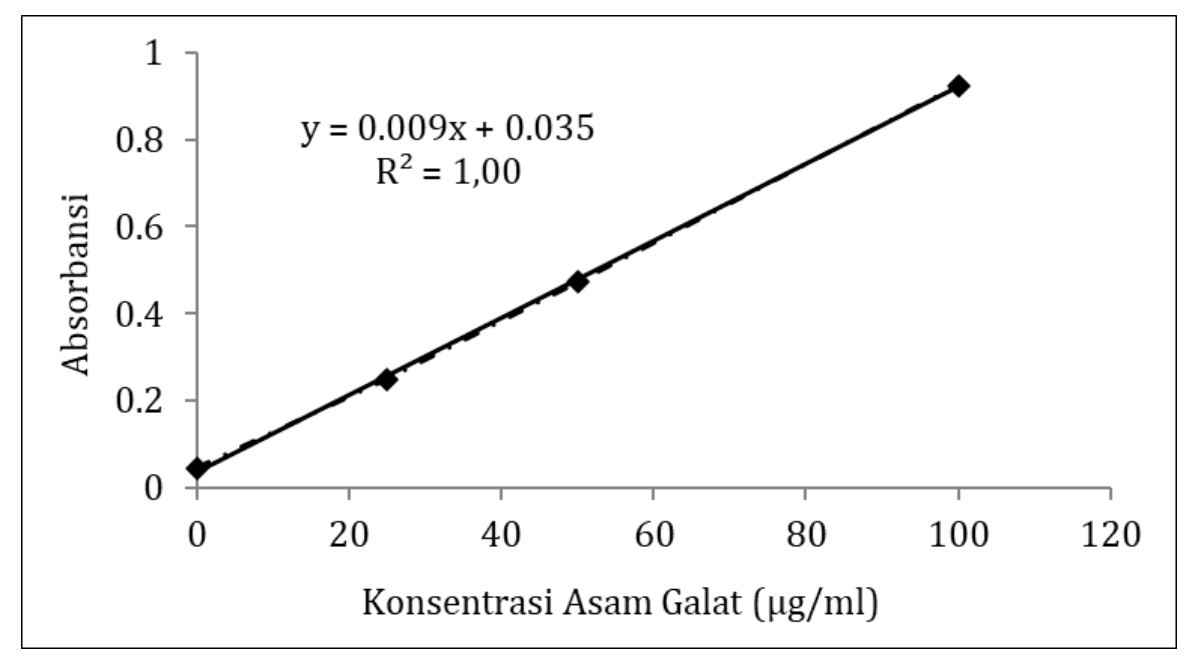

Gambar 1. Kurva baku konsentrasi asam galat terhadap absorbansi

Hasil penentuan kandungan total fenol ekstrak air daun afrika berdasarkan kurva baku pada Gambar 1., menunjukkan bahwa kandungan total fenol ekstrak air daun afrika sangat bervariasi bergantung pada konsentrasi ekstrak (Tabel 1). Hasil tersebut menunjukkan bahwa kandungan total fenol ekstrak air daun afrika yang digunakan dalam penelitian ini bervariasi menurut konsentrasi. Konsentrasi ekstrak sebesar $0,5 \%$ mengandung total fenol tertinggi, yaitu $69,89 \mu \mathrm{g} / \mathrm{ml}$, kemudian pada konsentrasi ekstrak yang lebih rendah, kandungan total fenolnya cenderung menurun. Tabel 1. Kandungan Fenol Ekstrak Air Daun

\begin{tabular}{cc} 
Afrika & \\
\hline $\begin{array}{c}\text { Konsentrasi } \\
\text { ekstrak }(\%)\end{array}$ & Total Fenol $\mu \mathrm{g}$ EAG/ml \\
\hline 0,0 & $0,00 \pm 0,00$ \\
0,1 & $18,81 \pm 0,35$ \\
0,2 & $33,46 \pm 0,25$ \\
0,3 & $44,54 \pm 0,60$ \\
0,4 & $53,57 \pm 0,25$ \\
0,5 & $69,89 \pm 3,18$ \\
\hline
\end{tabular}


Senyawa fenolik merupakan kelompok senyawa dengan gugus hidroksil yang berikatan dengan hidrokarbon aromatik (Saxena dkk., 2013). Senyawa fenolik yang diekstraksi dari berbagai sumber tumbuhan telah dibuktikan memiliki berbagai aktivitas farmakologis. Senyawa fenolik dilaporkan memiliki efek farmakologis, yaitu pencegahan penyakit pembuluh darah jantung, antikanker dan aktivitas antidiabetes (Abbas dkk., 2017), antimikroba, antiviral, antioksidan, antiinflamasi dan antikarsinogenik (Kabera dkk., 2014).

Senyawa fenolik merupakan senyawa metabolit sekunder yang melimpah di dalam tumbuhan (Kabera dkk., 2014). Kelompok senyawa fenolik dalam tumbuhan meliputi asam fenolat, flavonoid dan polifenol (Saxena dkk., 2013). Senyawa fenolik yang berasal dari tumbuhan dilaporkan bersifat antioksidan yang kuat bahkan memiliki aktivitas antioksidan yang lebih tinggi dari vitamin $\mathrm{C}$ (Dai dan Mumper, 2010).

\section{Kapasitas Stabilisasi Radikal Bebas DPPH}

Pengujian kapasitas stabilisasi radikal bebas dari ekstrak air daun afrika bertujuan untuk mengetahui kemampuan ekstrak sebagai penangkal radikal bebas melalui reaksi donasi atom hidrogen terhadap radikal DPPH. DPPH merupakan molekul radikal bebas yang memiliki jumlah elektron ganjil yang terdelokalisasi sehingga memberikan warna ungu tua dalam larutan. Intensitas warna ungu tua akan menurun bila larutan DPPH direaksikan dengan senyawa yang dapat menyumbangkan atom hidrogen (Kedare dan Singh, 2011).

Hasil pengujian kapasitas stabilisasi radikal bebas ekstrak air daun afrika memperlihatkan bahwa ekstrak air daun afrika memiliki kapasitas menstabilkan radikal bebas DPPH melalui donasi atom hidrogen. Kapasitas stabilisasi radikal bebas ekstrak cenderung meningkat dengan meningkatnya konsentrasi ekstrak sampai pada batas konsentrasi $0,3 \%$. Selanjutnya peningkatan konsentrasi ekstrak dari konsentrasi 0,3\% menjadi $0,4 \%$ dan $0,5 \%$, cenderung menurunkan kapasitas stabilisasi ekstrak daun afrika terhadap radikal bebas DPPH (Gambar 2).

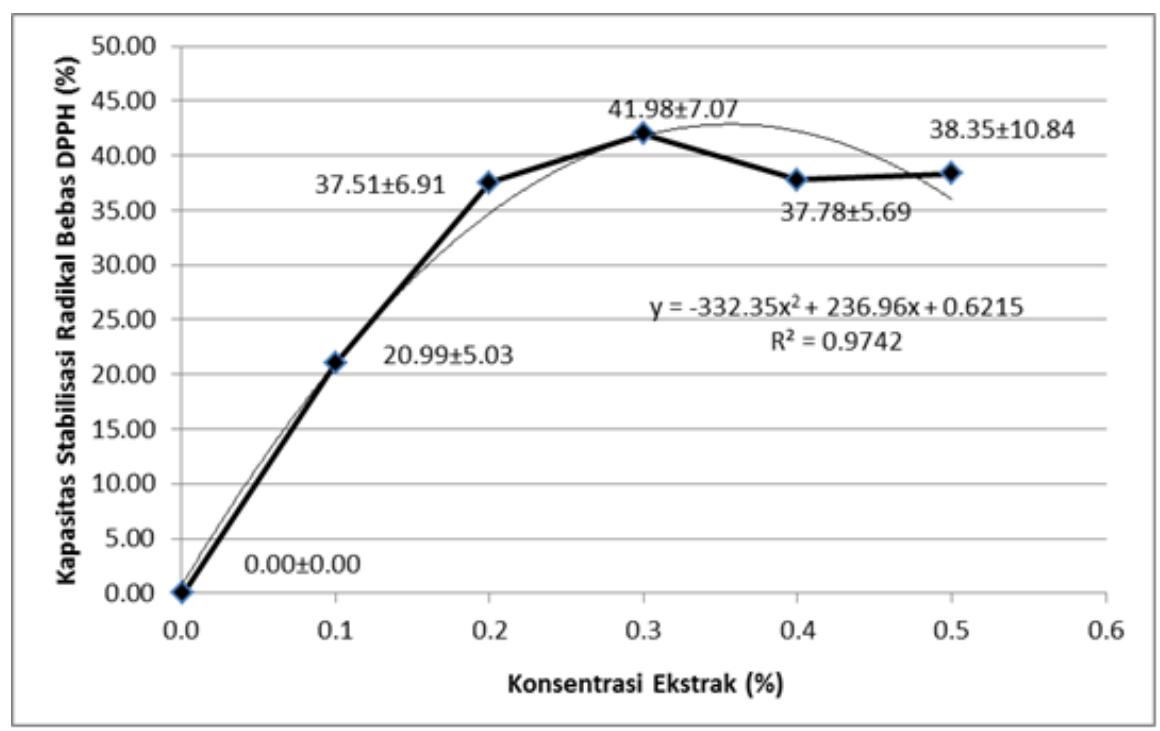

*Kapasitas stabilisasi vitamin C konsentrasi $60 \mathrm{mg} / \mathrm{ml}(0,06 \%)$

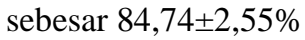

Gambar 2. Kapasitas stabilisasi radikal bebas dpph ekstrak daun afrika

Analisis regresi menunjukkan bahwa kapasitas stabilisasi ekstrak daun afrika dari 0$0,5 \%$ mengikuti pola kurva polynomial orde 2 persamaan $\mathrm{Y}=-332,35 \mathrm{X} 2+236,96 \mathrm{X}+0,62$ dengan koefisien regresi $\mathrm{R}^{2}=0,97$. Hasil analisis regresi tersebut menunjukkan bahwa konsentrasi optimum ekstrak daun afrika dalam menstabilkan radikal bebas DPPH adalah sekitar $0,3 \%$ dengan kapasitas stabilisasi radikal bebas sebesar $41,98 \%$.

Kapasitas stabilisasi radikal bebas DPPH ekstrak air daun afrika relatif rendah dibandingkan dengan jenis ekstrak yang lain. Fraksi ekstrak n-Heksan dan metanol daun 
afrika memiliki kapasitas stabilisasi radikal sebesar 50\% pada konsentrasi ekstrak masingmasing sebesar 0,04 dan $0,02 \%$ (Febrianti dkk., 2017; Fatimah dan Sundu, 2020) Kapasitas stabilisasi radikal bebas ekstrak daun afrika juga relatif lebih rendah dibandingkan dengan vitamin $\mathrm{C}$ dengan konsentrasi 60 $\mathrm{mg} / \mathrm{ml}$ atau setara dengan $0,06 \%$ yaitu sebesar $84,74 \%$. Hasil tersebut menunjukkan bahwa ekstrak air daun afrika kurang berpotensi sebagai sumber antioksidan alami dalam menstabilkan radikal bebas.

\section{Kapasitas Kelasi Ion Metal Ekstrak Daun Afrika}

Pengujian kapasitas kelasi ion metal ekstrak air daun afrika dilakukan terhadap senyawa ion metal $\mathrm{Fe}^{+2}$. Pengujian ini bertujuan untuk mengetahui kemampuan ekstrak mengikat ion $\mathrm{Fe}^{+2}$. Ion $\mathrm{Fe}^{+2}$ merupakan ion yang bersifat mempercepat proses oksidasi (prooksidan) dalam pembentukan radikal bebas (Ionescu dan Poljsak, 2010).

Hasil pengujian kapasitas kelasi ion $\mathrm{Fe}^{+2}$ ekstrak daun afrika menampilkan bahwa pada konsentrasi ekstrak daun afrika $0-0,3 \%$ terjadi peningkatan kapasitas kelasi ion metal $\mathrm{Fe}^{+2}$ seiring dengan meningkatnya konsentrasi. Peningkatan konsentrasi dari $0,3 \%$ menjadi $0,4 \%$ cenderung menurunkan kapasitas kelasi ekstrak dari $37,48 \%$ menjadi $28,11 \%$ sedangkan konsentrasi $0,5 \%$ menghasilkan kapasitas kelasi ion metal $\mathrm{Fe}+2$ tertinggi, yaitu $40,71 \%$. Hasil analisis regresi menunjukkan bahwa peningkatan konsentrasi cenderung meningkatkan kapasitas kelasi ion metal $\mathrm{Fe}^{+2}$ ekstrak dan afrika. Pola peningkatan kapasitas kelasi ion metal $\mathrm{Fe}^{+2}$ menurut konsentrasi mengikuti persamaan linear $\mathrm{Y}=79,998 \mathrm{X}+$ 2,526 dengan nilai $\mathrm{R}^{2}=0,862$ (Gambar 3).

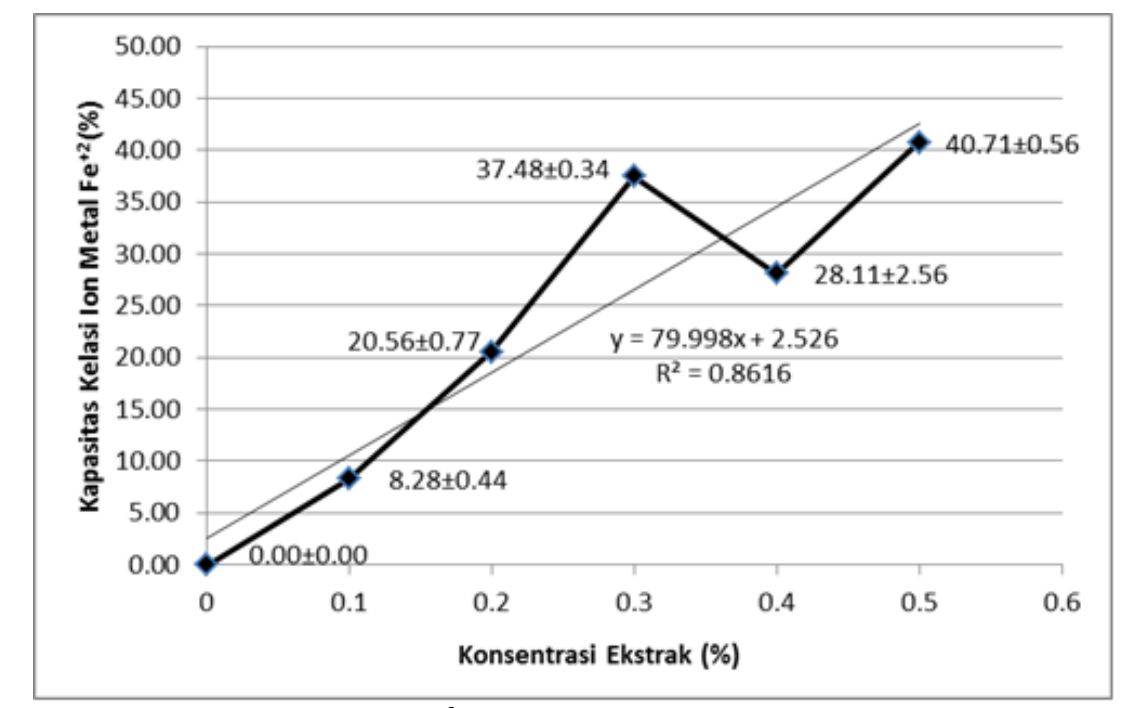

*Kapasitas kelasi ion metal $\mathrm{Fe}^{+2}$ vitamin $\mathrm{C}$ konsentrasi $0,5 \%$ sebesar 5,75 $\pm 1,40 \%$

Gambar 3. Kapasitas kelasi ion metal $\mathrm{Fe}^{+2}$ ekstrak daun Afrika

Gambar 3 juga menunjukkan bahwa ekstrak daun afrika konsentrasi $0,5 \%$ memiliki kapasitas kelasi ion $\mathrm{Fe}^{+2}$ yang lebih tinggi dibandingan vitamin $\mathrm{C}$ pada konsentrasi yang sama. Kapasitas kelasi ion metal $\mathrm{Fe}^{+2}$ ekstrak daun afrika dan vitamin $\mathrm{C}$ pada konsentrasi $0,5 \%$ masing-masing sebesar $40,71 \%$ dan $5,75 \%$. Hasil tersebut menunjukkan bahwa ekstrak daun afrika memiliki kapasitas kelasi ion metal $\mathrm{Fe}^{+2}$ sebesar 7,01 kali lebih tinggi dibandingkan dengan vitamin C. Hasil tersebut menunjukkan bahwa ekstrak air daun afrika berpotensi sebagai sumber antioksidan alami sebagai penyumbang elektron terhadap ion metal yang bersifat mempercepat proses oksidasi molekul (prooksidan).

\section{KESIMPULAN}

Ekstrak air daun afrika memiliki kapasitas stabilisasi radikal bebas optimum pada konsentrasi $0,3 \%$ sebesar $41,98 \%$ dan kelasi ion metal $\mathrm{Fe}^{+2}$ sebesar $40,71 \%$ pada konsentrasi $0,5 \%$. Kapasitas kelasi ion metal ekstrak air daun afrika 6,50 kali lebih tinggi dari vitamin C. Esktrak air daun afrika kurang berpotensi digunakan sebagai sumber antioksidan alami dalam menstabilkan radikal 
bebas namun sangat efektif mengikat ion metal yang bersifat prooksidan.

\section{DAFTAR PUSTAKA}

Abbas, M., Saeed, F., Anjum, F. M., Afzaal, M., Tufail, T., Bashir, M. S., Ishtiaq, A., Hussain, S., and Suleria, H. A. R., (2017), Natural Polyphenols: An Overview, International Journal of Food Properties, 20(8), pp. 1689-1699.

Cepeda, G. N., Lisangan, M. M., Roreng, M. K., Permatasari, E. I., Manalu, D. C., dan Tainlain, W., (2018), Aktivitas Penangkalan Radikal Bebas dan Kemampuan Reduksi Ekstrak Kulit Kayu Akway (Drimys piperita Hook. f.), Jurnal Aplikasi Teknologi Pangan, 7(4),pp. 168-173.

Dai, J., and Mumper, R. J., (2010), Plant Phenolics: Extraction, Analysis and their Antioxidant and Anticancer Properties, Molecules, 15,pp. 7313-7352.

Farombi, E. O., and Owoeye, O., (2011), Antioxidant and Chemopreventive Properties of Vernonia amygdalina and Garcinia biflavonoid. International Journal of Environmental Research and Public Health, 8,pp. 2533-2555.

Fatimah, N., dan Sundu, R., (2020), Uji Aktivitas Antioksidan Fraksi n-Heksan Daun Afrika (Vernonia amygdalina Del.) dengan Metode DPPH, Jurnal Ilmiah Ibnu Sina, 5(2), pp. 250-257.

Febrianti, P., Prabowo, W. C., dan Rijai, L., (2017), Aktivitas Antioksidan dan Tabir Surya Ekstrak Daun Afrika Vernonia amygdalina Del., Proceeding of the $5^{\text {th }}$ Mulawarman Pharmaceuticals Conferences, Fakultas Farmasi Universitas Mulawarman, 23 - 24 April 2017, Samarinda.

Handa, S. S., (2008), An Overview of Extraction Techniques for Medicinal and Aromatic Plants, In Handa, S. S., Khanuja, S. P. S., Longo, G., and Rakesh D. D. (Ed). Extraction Technology for Medicinal and Aromatic Plants, International Centre for Sciences and High Technology, Trieste, pp.21-52.

Indracanti, M., and Sivakumar, Ch. V., (2019), Screening of Medicinal Plants for Iron Chelating and Antioxidant Activity, Biotechnology International, 12(2),pp. 30-36.
Ionescu J. G., and Poljsak B., (2010), Metal Ions Mediated Pro-Oxidative Reactions with Vitamin C: Possible Implications for Treatment of Different Malignancies, International Journal of Cancer Prevention, 3(3),pp. 1-26.

Islam, M. N., Kabir, M. S. H., Kader, S. Md. A., Hasan, M., Samrat, E. K., Habib, I. B., Jony, M. N. H., Chowdhury, M. S., Hasanat, A., and Rahman, Md. M., (2016), Total Phenol, Total Flavonoid Content and Antioxidant Potential of Methanol Extract of Boehmeria platyphylla D Don Leaves, World Journal of Pharmaceutical Research, 5(5),pp. 334-344.

Kabera, J. N., Semana, E., Mussa, A. R., and He, X., (2014), Plant Secondary Metabolites: Biosynthesis, Classification, Function and Pharmacological Properties. Journal of Pharmacy and Pharmacology, 2(7),pp. 377-392.

Kadiri, O., and Olawoye, B., (2016), Vernonia amygdalina: An Underutilized Vegetable with Nutraceutical Potentials - A Review. Turkish Journal of Agriculture - Food Science and Technology, 4(9),pp. 763-768.

Kasote, D. M., Katyare, S. S., Hegde, M. V., and Bae, H., (2015), Significance of Antioxidant Potential of Plants and Its Relevance to Therapeutic Applications. International Journal of Biological Sciences, 11(8),pp. 982-991.

Kedare, S. B., and Singh, R. P., (2011), Genesis and Development of DPPH Method of Antioxidant Assay. Journal of Food Sciences and Technology, 48(4),pp. 412-422

Nurlatifah, R., Dirgantara S., Gunawan, E., and Meiyanto, E., (2018), Uji Aktivitas Antioksidan Beberapa Tanaman Asli Papua dan Efek Kombinasinya. Prosiding Seminar Nasional Tumbuhan Obat Indonesia ke-55, 17-18 Oktober 2018, Magelang.

Ojimelukwe, P. C., and Amaechi, N., (2019), Composition of Vernonia amygdalina and its Potential Health Benefits. International Journal of Environment, Agriculture and Biotechnology, 4(6),pp. 1836-1848.

Pagare, S., Bhatia, M., Tripathi, N., Pagare, S., and Bansal, Y. K., (2015), Secondary 
Metabolites of Plants and their Role:

Overview. Current Trends in

Biotechnology and Pharmacy, 9(3), pp. 293-304.

Saxena, M., Saxena, J., Nema, R., Singh, D., and Gupta, A., (2013). Phytochemistry of Medicinal Plants, Journal of Pharmacognosy and Phytochemistry, 1(6),-pp.168-182.

Sukmawati, Hadi, H., dan Aminah., (2017), Potensi Senyawa Flavonoid Daun Afrika (Vernonia amygdalina Del.) Asal Ternate Sebagai Antioksidan. As-Syifaa, 9(2),pp. 195-200.
Tosa, N. 2018. Penentuan Kandungan Total Fenolik, Uji Aktivitas Antioksidan, Aktivitas Antibakteri dan Antijamur dari Ekstrak Tumbuhan Daun Afrika (Vernonia amygdalina Delile), [Skripsi], Fakultas Matematika dan Ilmu Pengetahuan Alam Universitas Andalas.

Yadav, A., Kumari, R., Yadav, A., Mishra, J. P., Srivatva, S., and Prabha, S., (2016), Antioxidants and Its Functions in Human Body - A Review. Research in Environment and Life Sciences, 9(11), pp. 1328-1331. 